POLIIICAL ECONOMY RESEARCH INSTIIUIE

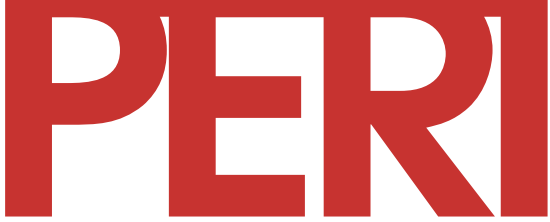

University of Massachusetts Amherst

\title{
The Lighthouse and the Potato: Internalizing the Value of Crop Genetic Diversity
}

\author{
Stephen B. Brush
}

2002

10th floor Thompson Hall University of Massachusetts Amherst, MA, 01003-7510 Telephone: (413) 545-6355 Facsimile: (413) 545-2921 Email:peri@econs.umass.edu Website:

http://www.umass.edu/peri/

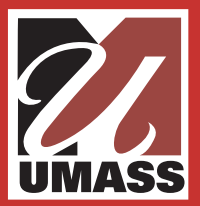


Working Paper No. 37

\section{The Lighthouse and the Potato: Internalizing the Value of Crop Genetic Diversity}

Stephen B. Brush

March 2002

A Paper for the Natural Assets Project

Funded by the Ford Foundation

Program on Development, Peacebuilding, and the Environment

Political Economy Research Institute (PERI)

University of Massachusetts Amherst 


\section{Introduction}

The incongruous juxtaposition of my title, "The Lighthouse and the Potato," refers to two public goods of incalculable value - safe navigation and crop genetic resources. Neither lighthouse keepers nor the farmers who cultivate genetic diversity in potatoes and other crops provide their respective benefits to humankind without cost. The costs of lighthouses are relatively easy to measure - construction of the tower, fuel for the light, wages for the keeper. The costs of sustaining crop genetic resources are less evident, but can be viewed as the income foregone by not switching to new varieties, new crops, or other economic pursuits. This foregone income is the functional equivalent of the costs of building and operating a lighthouse to provide the public good of safe navigation. The increasing availability of more profitable alternatives to growing traditional crops means that society must find ways to sustain diverse crop genetic resources and the environments where they are created and maintained - the small farms of poor farmers. We have long recognized that we cannot simply depend on the goodwill of coastal dwellers to maintain lighthouses for ships at sea (Coase 1974, van Zandt 1993). Gradually, we are becoming aware that we cannot depend on the goodwill of farmers to conserve crop genetic resources.

Crop genetic resources are a natural asset comprised of the genes of domesticated plants, together with the dynamic human and ecological contexts which are indispensable to a crop's evolutionary system. Abundance and diversity of these resources are concentrated in locations where crops were originally domesticated and/or long evolved under heterogeneous conditions. These locations are known as "Vavilov Centers" in honor of the great Russian botanist Nikolai Vavilov, who pioneered the study of crop origins in the early $20^{\text {th }}$ century. Today, the primary stewards of crop genetic resources in these centers of diversity, which continue to provide the foundation for agricultural development around the world, are poor farmers. This natural asset is increasingly threatened, however, by the economic marginalization of poor farmers, and by the competitive disadvantage of traditional crops compared to modern industrial agriculture. Genetic erosion, the loss of biological diversity and resources, is being caused by the replacement of local varieties by improved ones or by different crops altogether, and by the exodus of farmers to non-farm employment.

The farmers who historically have provided crop genetic resources as a public good receive no direct reward for doing so. Developing a system to reward them for stewardship of this public good - an example of the internalization route to natural asset building - would simultaneously advance the goals of poverty reduction and environmental protection. This paper argues that neither a state-centered régime nor the privatization of crop genetic resources is likely to succeed in stemming the loss of crop genetic resources. Instead, the paper proposes that crop genetic resources be preserved as a public good managed in common by farmers, and that farmers who maintain genetic resources be supported by public investment in community-based agricultural development. 


\section{Crop Genetic Resources}

The Vavilov Centers are located, virtually without exception, in developing countries, and within them crop genetic resources are concentrated on the poorest of farms. Several large gene pools of crop genetic resources are found in the Americas. These include food crops - the maize, bean, and squash complex of Meso-America, potatoes in the Andes Mountains, and manioc in the Amazon Basin - and high-value, specialty, and industrial crops, notably cacao, tomato, chile pepper, tobacco, and peanut. Prehistoric migration and crop diffusion established the principal crops of Meso-America throughout much of the continental US, where they evolved into distinct and diverse regional crop populations.

Crop genetic resources are conventionally divided into two broad groups: wild and weedy relatives of domesticated plants, and landraces or "primitive crop varieties" from farmers' fields. The landraces have been inherited from previous generations, and undergo continuous natural and artificial (that is, conscious) selection (Harlan 1975). Landraces are the most important crop genetic resource for agricultural science in terms of their historic value in crop breeding, proportion of material collected and stored in conservation facilities, and relevance to political conflicts. For most crops, landraces are counted in the thousands, and for some in the tens of thousands. This diversity embodies the collected wisdom and experience of the hundreds of generations of farmers who have selected and managed crop populations since the Neolithic Revolution, some 5000 to 8000 years ago.

Landraces form the backbone of the modern crop breeding industry. For instance, two farmer-selected varieties, Reid and Lancaster, dominate the inbred lines used in Corn Belt hybrid maize in the US (Wallace and Brown 1988). In the American wheat crop, the variety Norin 10 - which confers short stature to modern varieties and can be traced to landraces from Japan, Pennsylvania and Turkey (Brush 1996a) - is common in pedigrees of all wheat classes (Cox 1991). Currently, landraces represent 60\% of the 1,300 collections and 6.1 million accessions in over 120 national and international gene banks; the remainder are in selected and bred varieties, breeding lines, and wild and weedy relatives (FAO 1996).

While the social value of landraces has been demonstrated time and again in modern plant breeding programs (Evenson et al. 1998), their private value to the farmers who maintain them is increasingly jeopardized. The availability of purchased inputs such as fertilizer and pesticides, the existence of improved crop varieties, and the opportunities to increase income by changing crops, land uses, or employment all diminish the incentives for farmers to grow landraces. In addition, low grain prices from industrialized agriculture are transmitted via international trade, such as US maize exports to Mexico (Boyce 1996), often to the detriment of the small farm sector that maintains traditional crop varieties.

Despite the immense value of landraces and the importance of conserving them, the understanding of their genetic structure and their relation to farming groups is poorly developed. While crop population biology is an active field of research, the task of describing the biological and social ecology of these dynamic species is daunting. Considerable effort has gone into understanding the evolutionary history of modern crops, in particular their relation to wild and weedy relatives. Far less effort has been devoted 
to mapping the distribution of crop diversity across the agricultural landscape, and its relation to social and cultural diversity. ${ }^{1}$

Crop diversity is distributed within and across localities. In theory, it is conceivable that each individual locality hosts a genetically distinct population of the crop. At the other extreme, different regions may be sown with the same crop population, that is, the same mix of varieties. In the first case, where diversity is found entirely between localities, genetic resources are easily connected to particular people and places. In the latter case, no single site can be identified with specific genetic resources because they are shared across many localities. The distribution of diversity is critical to claims of ownership or rights to private benefit from genetic diversity.

Several factors favor the distribution of diversity between rather than within localities, and hence a tendency toward a situation where each farming region is genetically distinct. Most prominent is the importance of local adaptation in agricultural systems that offer few other management tools to contend with risks such as drought, insect attack, or disease outbreaks. Harlan's (1975) classic definition of landraces stresses that these are crop populations in balance with their local environments. Adaptation to different micro-environments could be the major reason why there is so much diversity. Another factor favoring a high proportion of diversity between rather than within localities is the physical and social isolation of farming communities: mountainous terrain, cultural and linguistic heterogeneity, and the lack of integrating mechanisms, such as markets, pose barriers which help to protect local varieties.

On the other hand, countervailing factors encourage the flow of genetic material between communities, fostering diversity within rather than between localities. As "pioneer species" that compete well in newly cleared land, crops by nature are able to exploit diverse habitats, and often are broadly rather than narrowly adapted. Historically, broad adaptation allowed very rapid diffusion of species domesticated in one place to other places around the world. Moreover, farmers have long sought to increase returns to land and labor through experimentation and exchange of knowledge and seeds. Seed exchange between farming communities is also necessitated by the loss of seed and by seed degeneration, and can be accelerated by changes in diet and taste. Seed-exchange networks and/or markets quickly diffuse local varieties found to possess valuable characteristics such as disease resistance, drought tolerance, or special culinary qualities. Even a small amount of exchange between communities each year can result in thorough mixing of crop populations over time. Seed exchanges have resulted in the wide distribution of particular farmed varieties even in the most "traditional" agricultural communities (Brush et al. 1995; Louette et al. 1997; Zeven 1999).

${ }^{1}$ In the past, philanthropic institutions such as the Ford and Rockefeller Foundations supported pioneering efforts to collect and study resources in Asia and MesoAmerica (e.g., Wellhausen et al. 1952). Today these institutions could provide critical support for understanding the ecology of crop diversity and designing conservation programs that involve farmers. One example of such philanthropic support is the McKnight Foundation's project in Mexico called "Milpa: A Farmer-Based Approach to Conserving and Improving Mexican Crops" (Genetic Resources Conservation Program 2000). 
Factors that encourage a close correspondence between social group and an inventory of crop genetic resources include (i) the propensity for local adaptation by crop varieties, (ii) environmental heterogeneity and isolation of specific farming communities or cultural groups, (iii) equivalence between the territory of a social group and a unique agricultural environment, (iv) a lack of markets for seed or other agricultural inputs, and (v) selection for local tastes and uses. Factors that weaken correspondence between social group and crop genetic resources include (i) sharing of a single agricultural environment by two or more social groups, (ii) migration by social groups between agricultural environments, (iii) markets or other exchange mechanisms that cut across social groups, and (iv) crop introduction and improvement programs that utilize crop germplasm from different sources. Both sets of factors are found in virtually every farming system, whether in "traditional" small-farm sectors or "modern" industrial farms. Therefore, a close correspondence between a social group and a particular inventory of crop genetic resources cannot be assumed a priori. As discussed below, this issue weighs heavily on whether genetic resources should or could be privatized.

\section{Alternative Ways to Confront Genetic Erosion}

Crop genetic resources in farmers' fields have historically been treated as assets that generate positive externalities, whose only cost is that of collection, and for whose loss no one bears liability. The issue today is whether, and if so how, to change this treatment of crop genetic resources so that the costs and benefits of producing and maintaining them are acknowledged and internalized into the international agricultural system.

For individual farmers and communities, the declining variability in crop populations is a byproduct of the quest for higher productivity. The originally diverse crop inventories of North America were almost entirely eliminated in the development of modern American agriculture. For instance, as a result of the diffusion of hybrid maize, remnants of the original North American maize varieties are found only in isolated islands of traditional agriculture, notably in the US southwest among Native Americans (Nabhan 1985, Soleri and Cleveland 1993). Further south, in the Meso-American, Andean, and Amazonian Vavilov Centers, crop genetic resources retain some of the integrity of pre-modern agriculture, albeit under increasing threat of genetic erosion. These crop genetic resources are concentrated in the poorest farm sectors, among small farmers and indigenous producers: Hopi maize farmers in Arizona, Otomi and Maya maize farmers in Mexico, Quechua and Aymara potato farmers in the highlands of Peru and Bolivia, Amuesha manioc farmers in the Peruvian Amazon. In these very poor sectors, the pressures to augment food production and incomes are great, driving a wedge between the private value of traditional crops to farmers and their social value to crop breeders and consumers worldwide. These sectors offer the greatest potential benefits from reconciling economic incentives with the world's need to maintain these unique seed stocks.

Reconciling private and social values across national boundaries, and across highly contrasting social and economic groups, is central to international efforts to staunch the loss of biological diversity. Such reconciliation is an aim of the Convention on Biological Diversity (CBD), an international agreement 
initialed in 1992 that recognized national sovereignty over genetic resources, and thereby foreshadowed a property system over them. The CBD represents a step toward a negotiated settlement between parties who manage genetic resources and parties interested in their conservation. Such a settlement represents an application of the Coase (1960) Theorem, which suggests that bargaining between parties can bring an externality to a socially optimal balance between private and social costs, as long as one party is assigned property rights relative to the externality.

Three alternative ways to confront genetic erosion can be distinguished: (i) a state-centered approach, in which governments assume responsibility for conservation, (ii) a privatization approach, in which farmers assume this responsibility, and (iii) a community-based approach, in which a partnership between public and private interests provides for joint responsibility. Today the state-centered approach is dominant, relying on off-site (ex situ) maintenance of genetic resources and providing no recognition of farmers' interests or rights. The CBD's emphasis on sovereign control of biological resources also suggests a state-centered approach, in which it remains unclear whether and how states will negotiate with farmers to reduce genetic erosion. Privatization would circumvent direct state negotiation, shifting ownership rights to genetic resources to the farmers who produce them and involving direct negotiation with the farmers concerning conservation. The third avenue represents an intermediate path between the statecentered and privatization alternatives, one which would maintain crop genetic resources as part of the public domain, but establish community-based mechanisms to conserve crop genetic resources.

\section{Common Heritage and the State-Centered Approach}

Two characteristics, centralized institutions for the conservation of crop genetic resources and the conceptualization of these resources as the "common heritage" of humankind, define the state-centered approach. Crop genetic resources, such as maize germplasm from Meso-America and potato germplasm from the Andes, historically have been provided as a public good in an open-access regime known as common heritage. The principle of common heritage holds that genetic resources, whether the resources are found in farmers' fields or gene banks, belong in the public domain. At their point of origin, access to genetic resources is implicitly mediated only by the willingness of the farmer to provide a sample of his/her crop. Likewise, the custom of crop collectors, conservators, and breeders has been to provide free access to crop genetic resources, mediated only by the credentials of the user who requests samples, and the availability of seeds. Once crop resources have been brought into the publicsector national and international systems of conservation and utilization, they are treated explicitly as open-access goods available to all bona fide crop breeders and other scientists. In addition to insisting that genetic resources remain in the public domain, this common heritage approach makes their conservation a public responsibility by vesting it in government and international agencies. Traditionally, the costs of genetic resource conservation under this scheme were only the costs of collection, storage, and distribution from publicly-owned gene banks. These costs were borne by government and international agencies, without compensation to farmers, collectors, or conservators who provided the genetic resources. 
Common heritage, however, does not exclude all private ownership of genetic traits. Once traits have been isolated and used to create new crop varieties, the gene sequence or the variety can be privatized as intellectual property. The contradiction between open access to plants in the farmer's field and privatization of plants in the seed company's test plots is consistent with the usual logic of intellectual property, whereby goods from the public domain can be drawn upon to create private goods. Nevertheless, this contradiction is politically flammable when it is applied across boundaries defined by nationality, economic class, and cultural group (Shiva 1997; Fowler and Mooney 1990). There is little mystery that poor nations, peasant farmers, and indigenous people often interpret common heritage as a facade for the appropriation of biological assets.

In recent years, the historic principles of common heritage and state-centered conservation have begun to break down. The assault on common heritage, which culminated in the Convention on Biological Diversity's assertion of ownership of biological resources by sovereign states, was presaged on the one hand by the creation of intellectual property in crop varieties and other biological materials, and on the other by an international dialogue about the need to compensate traditional farmers, indigenous people, and other social groups who have conspicuously contributed to the world's store of biological resources (e.g., Fowler and Mooney 1990). The emergence of the concept of "biopiracy," defined as the "unidirectional and uncompensated appropriation" of plant genetic resources from developing countries (Odek 1994, 145), signals the close of the era of uncritical acceptance of the principle of common heritage. The image of theft is now widespread despite the fact that successful reciprocal relationships between providers and collectors of genetic resources can be demonstrated under the common heritage regime (Brush 1996a). Nevertheless, the principle of common heritage persists in the steadfast adherence to open access and public ownership of genetic resources by major institutions around the world, including the US National Germ Plasm System and international collections of the world's most important crops, jointly managed by the Food and Agriculture Organization (FAO) of the United Nations and the Consultative Group for International Agricultural Research (CGIAR).

At the same time that the legitimacy of the common heritage model is under attack, there is growing recognition of the inadequacy of the state-centered management of genetic resources via centralized conservation in "gene banks." Gene banks are a primary means for conserving genetic resources, but genetic erosion can only be partially countered by collecting and preserving landraces and other resources in off-site (ex situ) facilities. Crop scientists and conservators have become increasingly convinced of the need to maintain at least some portions of the agricultural environments that originally generated crop genetic resources. One reason for this is that gene banks simply cannot maintain the vast variability of crop genes. A second reason is that crop evolution in the field continues to generate a flow of new genetic material, whereas collections can at best maintain existing stocks. Thirdly, the possibility of failure of ex situ conservation makes it prudent to maintain a backup system. Finally, gene banks are effective for conserving the "hardware component" of crop genetic resources (e.g., alleles) but not the accompanying "software" (e.g., local knowledge and farmer selection practices). The fiction of the adequacy of gene banks allows states either to overlook the poverty and marginalization that threaten farmers who produce and maintain genetic resources, or to promote misguided economic development schemes that result in the destruction of those resources as a side effect. In sum, gene banks can be 
seen as the equivalent of zoos for the conservation of biological resources. They do not represent a comprehensive solution to conserving natural assets.

Were it not for the inadequacy of the centralized, gene-bank approach to conserving genetic resources, the sovereignty clause of the CBD might appear to resolve the issue of balancing the private and social values of genetic resources by multilateral negotiation between states. Conservationists of genetic resources now recognize, however, that some form of on-farm (in situ) conservation is necessary to complement ex situ conservation. This requires that farmers continue to practice active seed selection, exchange, and maintenance, sustaining local crop populations as a dynamic and evolving component of the agricultural environment. The challenge is to find a means to raise the private value of these natural assets to match more closely their high social value.

The CBD continues the state-centered approach in that it retains the public good and public domain aspects of genetic resources for farmers within the nation, while making state institutions the direct beneficiaries of negotiated international access. A multilateral variant of the state-centered approach is the Farmers' Rights proposal at the FAO, intended to create an international mechanism to accumulate funds from industrial countries that import genetic resources, and to disburse funds to developing countries that export genetic resources (Brush 1992; Esquinas Alcazar 1998). The funds are meant to assist farmers and farming communities, especially in the areas of origin and diversity of plant genetic resources (Esquinas Alcazar 1998, 209). This proposal remains state-centered, however, in its emphasis on keeping national rights over genetic resources and its assumption of the primacy of national institutions.

An inherent flaw in any state-centered approach is that the state interest in providing inexpensive food to urban populations has historically biased state policies against farmers who produce genetic resources farmers who are often ethnic minorities on small farms in marginal agricultural zones. This helps to explain the failure of national institutions in gene-rich countries to articulate a farmer-based plan to conserve genetic resources. The Farmers' Rights proposal so far has been stymied by the reluctance of some industrial countries to agree to a poorly defined expansion of rights over genetic resources, by the lack of agreement on how to finance the international fund, and by the proposal's failure to stipulate exactly how funds would be used. Meanwhile, some major exporters of genetic resources have been reluctant to agree to a multilateral agreement when potentially more lucrative bilateral agreements are possible.

\section{Privatization and Bio-Prospecting}


Accepting that the era of undisputed common heritage has passed, we can envision a continuum of mechanisms to provide access to genetic resources and benefit sharing for their producers and stewards. At one extreme are the state-centered approaches discussed above. At the other is privatization of genetic resources by individual farmers or small groups of farmers. This extreme is exemplified by "bio-prospecting" contracts between pharmaceutical or seed companies and communities in which the companies receive exclusive access to genetic resources in exchange for short- and long-term financial returns.

The problem of genetic erosion appears to offer a promising situation for such 'Coasian" bargaining solutions. The loss of crop genetic diversity is an externality for which state regulation is not a feasible option, since the governments in the Vavilov Centers have neither the incentive nor the means to mandate farmers to plant diverse traditional crop varieties. On the contrary, governments are actively involved in promoting agricultural development to increase food production, farm incomes, and food availability; and the replacement of local crop varieties with improved varieties is a proven method for reaching these development goals. If regulation cannot reduce the externality of genetic erosion, then bargaining between the producers and users of crop genetic resources would seem to offer a logical solution.

This approach is epitomized by the bio-prospecting contracts signed by ShamanBotanicals.com (née Shaman Pharmaceuticals) and indigenous communities in the Amazon (King et al. 1996). Contracts are logical ways to structure the relationship between the CBD's categories of "sources" and "users" of genetic resources (Gollin and Laird 1996; Cleveland and Murray 1997). Contracts provide short-term benefits - cash, materials or services - to persons and communities that allow collection of biological samples and local knowledge about those samples. In addition, bio-prospecting contracts may also provide for long-term benefits in the form of a share of royalties, normally less than five percent, on inventions that use the material collected. In theory, bio-prospecting contracts offer a simple and direct way to increase the private value of crop germplasm, and thereby to reward stewardship, promote conservation, and provide for reciprocity from groups that benefit from genetic resources (Sedjo 1992; Vogel 1994).

According to the tenets of the Coase Theorem, two conditions must hold if bio-prospecting contracts are to be effective in resolving the negative externality of genetic erosion: property rights must be welldefined, and transactions costs must be small enough to permit a mutually beneficial bargain. On one side of the contract, companies investing in bio-prospecting expect an intellectual property framework to protect the results of that investment (Gollin and Laird 1996). An array of different intellectual property mechanisms is already available to protect improved crop varieties - including plant variety protection, utility patents, and trade secrets (Baeziger et al. 1993). The Global Agreement on Trade and Tariffs (GATT) and its attendant agreement on Trade-Related Aspects of Intellectual Property Rights (TRIPS) project intellectual property in biological materials across national boundaries (Lesser 1998). 
Implicit ownership by the gene providers is the other side of the bio-prospecting contract. Indigenous peoples' and human rights organizations have asserted the natural right to intellectual property over biological resources (e.g., Shiva 1997; Posey and Dutfield 1996). For instance, the 1993 Mataatua Declaration, drafted at the First International Conference on the Cultural and Intellectual Property Rights of Indigenous Peoples held in New Zealand, proclaims that intellectual property is a right implied in the right of self-determination: "We declare that Indigenous Peoples of the world have the right to self determination, and in exercise of that right must be recognized as the exclusive owners of their cultural and intellectual property" (Posey and Dutfield 1996, 205). This reaffirmed assertions of earlier assemblies, notably Agenda 21 of the United Nations Conference on Environment and Development (Robinson 1993), the Kari-Oca Declaration and the Indigenous Peoples' Earth Charter, and the Charter of the Indigenous-Tribal Peoples of the Tropical Forests (Posey and Dutfield 1996). The unratified UN Draft Declaration on the Rights of Indigenous People (Part IV.29) similarly affirmed in 1993 that "indigenous peoples are entitled to the recognition of the full ownership, control, and protection of their cultural and intellectual property" (Posey and Dutfield 1996, 186).

These claims are largely rhetorical, and nation-states in countries with genetic resources seem unlikely to grant intellectual property rights over diffuse "indigenous knowledge" to indigenous peoples. The ambiguity of defining "indigenous," the relatively small populations of people so defined, and their economic and political marginality do not favor state policies to establish indigenous intellectual property. Nevertheless, the government of the Philippines has created a precedent for such policies in Republic Act 8371, signed in 1997, which recognizes the rights of Indigenous Cultural Communities and Indigenous Peoples: "to special measures to control, develop and protect their sciences, technologies and cultural manifestations, including human and other genetic resources, seeds, derivatives of these resources, traditional medicines and health practices, vital medicinal plants, animals and minerals, indigenous knowledge systems and practices, knowledge of the properties of fauna and flora, oral traditions, literature, designs, and visual and performing arts" (Republic of the Philippines 1997).

Coupling this precedent with the recognition of intellectual property for improved crop varieties, the property rights preconditions for Coasian bargaining solutions may be emerging. Nevertheless, bioprospecting contracts confront another substantial problem in the form of transaction costs. Critical reviews of the "Coase Theorem," including that of Coase himself (1988), stress that the zero transaction cost condition assumed in the theorem does not hold in real-world situations. In negotiations to reduce genetic erosion, transaction costs are pertinent in two ways. First, the costs of bargaining may exceed the value of the genetic resources, blocking any deal. Second, the transaction costs may affect the equity of the outcome, especially if they are higher for one party.

Two generic transaction costs described by Arrow (1969) are particularly relevant in the case of genetic resources: exclusion costs, and the costs of communication and information. Exclusion refers to the "free-rider" problem, when persons can benefit from a bargained solution without incurring its costs. In the case of contracts between producers and users of crop genetic resources, the costs of exclusion would presumably be extremely high due to the wide diffusion of crop genes in farming communities that are not parties to the contract (Brush et al. 1995). This diffusion weakens ownership claims. The 
collector who pays for access to a community's genetic resources would logically wish to see that other collectors who do not pay are denied access, but the population structure of landraces and the ubiquity of seed exchange make it reasonable to expect that similar or identical genetic resources exist in other communities that are not included in the contract. On the other side, a community that negotiates a contract might want to increase its value by excluding other communities from negotiating similar, competitive contracts. Such exclusion, however, would incur the cost of determining the distribution of the genetic resource prior to the contract, and of establishing one community's rights vis-à-vis the others. Furthermore, a legacy of the common heritage principle is the existence of sizeable national and international collections of crop genetic resources that are chartered to provide germplasm openly to bona fide scientists. Another legacy is the research exemption in many plant variety protection systems, which allows crop breeders to utilize material developed by another without paying a royalty. Both legacies pose legal barriers to exclusion.

The costs of communication and information are also likely to be high in bargaining between producers and users of genetic resources. Uncertainty about future benefits poses extremely high information costs to firms; this is likely to lower the amount a firm will invest in a bio-prospecting contract. For the seller, information on the value of genetic resources is made costly by social and economic inequality, and the paucity of communication between the farmers and the industrial scientific sector. This is exacerbated by the fact that few seed companies are active in collecting genetic resources, so that farmers often face a "bargaining" situation of monopsony, in which they have only one potential buyer of their resource.

These transaction costs not only threaten the efficiency of a bargaining solution to genetic erosion but also are likely to lead to inequities. A bio-prospecting contract between one community and a seed company may deny an equal opportunity to other communities with similar biological assets (Brush 1998). The costs of exclusion are almost certainly proportionately higher for farmers than for seed companies. The problem of monopsony in seed acquisition has already been mentioned. In addition, seed companies have alternative options, since they can also obtain genetic resources from public gene banks, and with the rise of biotechnology, can incorporate germplasm from other organisms. Farmers lack such fall-back options. As a result, most of the bargaining power is in the hands of the seed company, so that for the farmers, bio-prospecting is less a bargain than a take-it-or-leave-it proposition.

\section{Community-Based In Situ Conservation}

Both the state-centered and privatization approaches are problematic for addressing the welfare and environmental goals in the conservation of crop genetic resources. States have historic biases against on-farm conservation of crop genetic resources. Privatization through bio-prospecting is inequitable in allocating ownership of public goods to specific communities, and is unlikely to be effective as a conservation tool because of high transaction costs. Nevertheless, both approaches have some positive attributes: the state-centered principle of maintaining genetic resources as public goods in the public domain is valuable as a means to avoid the inequities of privatization, and the decentralized aspect of privatization is valuable as a means to avoid the biases of the state-centered approach. 
An alternative that combines the advantages of public domain and decentralization is needed to support in situ conservation of crop genetic resources. In the past decade, in situ conservation has emerged as a new strategy for maintaining crop genetic resources (Brush 1999, Wood and Lenné 1997). While this strategy is still in its formative stages, future programs are likely to incorporate three components: (i) research, (ii) participatory plant breeding, and (iii) community development. The research component will draw on the biological and social sciences to study the status and dynamics of genetic diversity and to identify the appropriate areas and mechanisms for conservation. Research in Mexico (Perales et al. 1998) and Turkey (Meng et al. 1998) has demonstrated how interdisciplinary collaboration between social and biological sciences can identify target areas for in situ conservation, where the risk of genetic erosion is high and where conservation might be accomplished by incrementally increasing the value of landraces to farmers.

Participatory plant breeding can improve the value of local crop populations and make them more competitive for increasing food productivity and farmer incomes (Witcombe et al. 1996). This technique involves farmers and scientists in the identification of outstanding local crop populations, improved seed selection and management, recovery of "lost" varieties, improved information and seed exchange among farmers, and farmer selection of breeding material developed by scientists. In pilot projects, these mutual efforts have been shown to increase productivity (Sperling and Loevinsohn 1997). Participatory plant breeding has yet to be extensively adopted, however. National crop improvement programs have limited capacity to work at the community level, while non-governmental organizations (NGOs) with greater access to farm communities typically are limited in the scientific capacity needed to manage the population biology and long-duration aspects of plant breeding. Partnerships between national programs and NGOs are needed to promote participatory plant breeding and in situ conservation.

The community development component of in situ conservation includes both market and non-market strategies. Marketing linked to environmental and social causes has scored successes in high-value commodities such as coffee, botanical food supplements, and cosmetics (Wasik 1996). Urban markets in many countries have specialized in relatively high-value niches for local crops and produce. Certification systems for origin and quality exist in many countries, and could be expanded to certify the status of local varieties which conserve genetic resources. Investment in market research, development, and insurance could help to widen these markets. Non-market strategies for promoting knowledge and interest in traditional crops include the "diversity fair" - a regional exposition of local crop varieties where farmers exchange seed and information, and where public prizes, such as school supplies for a village, are used to stimulate participation. Another is the promotion of seed saver and seed-exchange networks, whose activities can include multiplying and distributing seeds of heirloom varieties that have been lost in farming communities but survive in gene banks (Tesemma and Bechere 1998).

Most of the institutions - international, governmental, and non-governmental - involved in genetic resource conservation now accept the need to undertake both ex situ and in situ conservation as complementary strategies. Progress in this direction will require neither new organizations nor centralized 
management, but rather a means to stimulate partnerships among organizations with complementary skills. A key stumbling block is financial support for on-farm conservation. So far, such support has been provided on a partial and ad hoc basis through the work of NGOs and multilateral agencies such as the Global Environmental Facility, the UN Development Program, and CGIAR centers working in collaboration with national agricultural research programs. However, there is no dedicated, stable funding mechanism.

\section{The Genetic Resources Trust}

A Genetic Resources Trust, established with funding from private, foundation and public sources, would create a financial mechanism for in situ conservation. The aim of the Genetic Resources Trust would be to enhance the private value of crop genetic resources to promote conservation, by involving public institutions operating in the public domain to support decentralized, community-based efforts. The challenge is to devise mechanisms to reward stewardship without recourse to privatization. The partners in the Genetic Resources Trust would include farm communities in Vavilov Centers of crop diversity, national and international research organizations focused on crop conservation and development, nongovernmental organizations specializing in community development and conservation, and organizations and groups who benefit from open access to genetic resources, including seed companies, industrialized countries, and the modernized farm sectors of developing countries.

The Genetic Resources Trust concept builds on the model of the Genetic Resource Recognition Fund (GRRF) at the University of California, Davis (UC Davis). UC Davis faculty established the GRRF following the cloning and patenting of a gene that confers resistance to a bacterial rice disease, Xanthomonas oryzae pv. oryzae ('Xoo'). The resistance gene was found in a wild rice from Mali, Oryza longistaminata. The Central Rice Research Institute in Cuttack, India, obtained a sample of the Malian wild rice, and found it to be resistant to multiple strains of the bacterium. In 1977, scientists at the International Rice Research Institute (IRRI) in Los Baños, Philippines, obtained and regenerated the sample, multiplied the clone, and found it to be resistant to all six known races of bacterial blight in the Philippines. From 1978 to 1990, Dr. G. S. Khush at IRRI conducted an intensive breeding program, crossing and back-crossing $O$. longistaminata with the widely-used rice variety IR24 which was susceptible to rice blight; eventually, Dr. Khush succeeded in transferring to IR24 the genetic material from $O$. longistaminata that coded for blight resistance, dubbed 'Xa21.' Dr. Khush gave the new, resistant lines of IR24 to Professor Pamela Ronald, a plant pathologist at UC Davis, who isolated and cloned the Xa21 gene at UC Davis in 1995 (Ronald 1997). UC Davis then patented Xa21 for licensing to commercial companies. At the same time, UC Davis agreed to provide the Xa21 gene to IRRI and breeders in developing countries for free. Since most rice breeding in the world is done in the public sector, and rice seed can be planted by farmers from year to year, the value of the Xa21 gene to commercial companies is likely to come from transference to crop species other than rice, where private-sector breeding and synthetic hybrids are more prevalent. 
Contributions to the UC Davis GRRF will come from three sources: licensee companies, the University, and the inventors. The option agreements contain a clause that triggers a licensing agreement in the event that the company "commercializes" a product containing Xa21, requiring them to make payments into the Fund. In addition, Professor Ronald and her fellow inventors will voluntarily contribute to the GRRF some of the royalties they receive from the companies in the event of commercialization. The University will use the revenues to support fellowships for graduate or post-doctoral students from designated countries in various disciplines of agriculture. Although the GRRF is a pilot program, still requiring additional design to stipulate how GRRF funds are to be used to aid conservation or to benefit farmers, it provides a novel alternative to the state-centered and privatization approaches discussed above. The exchange of benefits between users and suppliers in the GRRF concept does not involve payments per se, but rather reciprocating one public good (education, knowledge) for another (genetic resources). Other reciprocal mechanisms could include support for community development or participatory plant breeding programs that improve local welfare or raise the productivity and income of farmers. A similar mechanism could help in situ conservation efforts in centers of crop genetic diversity. In so doing, it could build on the work of an increasing number of NGOs and public institutions that are initiating in situ conservation projects around the world (Brush 1999), offering opportunities to support public rather than private solutions to benefit-sharing.

A Genetic Resources Trust cannot rely solely on benefit-sharing tied to commercial exploitation. Genetic resources remain public domain goods, and as such they require continued support from public sources. Consequently, the creation of the Genetic Resources Trust will depend also on the acceptance by public-sector donors of both the trust idea and of its program for in situ conservation. Previous support for the consortium of international agricultural research centers of the CGIAR provides a useful precedent. The Genetic Resources Trust might replace the existing funding mechanism for ex situ crop genetic resource conservation, augmented with the addition of in situ conservation. Alternatively, the existing funding mechanism for gene banks might remain in place, and the Genetic Resources Trust dedicated exclusively to on-farm approaches. In either case, the establishment of the Trust could be greatly aided by private foundation leadership and support, as was demonstrated in an earlier era in the creation of international agricultural research centers such as IRRI and the International Maize and Wheat Improvement Center (CIMMYT). Private foundations might, for instance, demarcate highpriority regions for in situ conservation, identify private and public agencies to collaborate in implementing new conservation programs, and help to negotiate long-term support from private and public interests who benefit from open access to genetic resources. 


\section{Conclusion}

In situ conservation will be sustainable only if the private value of genetic resources to farmers is increased to the point that sufficient numbers of them continue to maintain diverse crop populations and agricultural ecosystems that generate new flows of diversity. The public approach to genetic erosion proposed in this paper does not rely on the private mechanisms of bio-prospecting nor the statecentered arrangements of the Convention on Biological Diversity. Rather it seeks to enlist support from state agencies as partners in a broad consortium of governmental and non-governmental organizations. In spirit, this approach returns to the common heritage principle, but grafts onto it a more direct and formal system to achieve mutually reinforcing welfare and environmental protection goals through in situ conservation.

This solution, which builds on both the institutional practices of public-sector agricultural research and the cultural practices of farmers in keeping genetic resources in the public domain, is not without cost. Funding can build on existing public expenditures, by adding a new component designated for on-farm efforts, the Genetic Resources Trust. But accomplishing both in situ and ex situ conservation will require a higher level of investment than current conservation programs (National Research Council 1993).

In terms of this paper's original metaphors of the lighthouse and potato, the provisioning of crop genetic resources need not pass through the privatization experiment that proved to be short-lived in the case of lighthouses (Coase 1974). The compelling issue today is not how to privatize genetic resources to benefit a few farmers, but how to augment public investment in order to protect this essential natural asset's flow of benefits to the public domain. In situ conservation, backed by the funding mechanism of a Genetic Resources Trust, can provide a public means to increase the private value of landraces and crop genetic resources. For poor farmers, the benefits from this community-based solution will arguably be more broadly distributed and longer lasting than those from either state-centered or private approaches. 


\section{Acknowledgements}

I wish to thank James Boyce and Barry Shelley for suggestions and comments on an earlier draft. Research for this paper has been supported in part by the National Science Foundation and the University of California. My appreciation goes to the Ford Foundation for supporting the Natural Assets Project conference.

\section{References}

Arrow, K. J. 1969. "The Organization of Economic Activity: Issues Pertinent to the Choice Of Market Versus Non-Market Allocation." Joint Economic Committee, 91st Congress of the United States, 1st Session, The Analysis and Evaluation of Public Expenditures: The PPB System. Vol 1: 47-64. Washington, DC: US Government Printing Office.

Baenziger, P. S., R. A. Kleese, and R. F. Barnes, eds. 1993. Intellectual Property Rights: Protection of Plant Materials. Madison, WI: Crop Science Society of America.

Boyce, J. K. 1996. "Ecological Distribution, Agricultural Trade Liberalization, and In Situ Genetic Diversity." Journal of Income Distribution 6: 265-286.

Brush, S. B. 1992. "Farmers' Rights and Genetic Conservation in Traditional Farming Systems." World Development 20 (11): 1617-30.

—. 1996. "Is Common Heritage Outmoded?" in Valuing Local Knowledge: Indigenous People and Intellectual Property Rights, edited by S. Brush and D. Stabinsky. Washington, D.C.: Island Press.

- 1998. "Bio-cooperation and the Benefits of Crop Genetic Resources: The Case of Mexican Maize." World Development 26: 755-766.

Brush, S. B., ed. 1999. Genes in the Field: On-Farm Conservation of Plant Genetic Resources. Boca Raton, FL: Lewis Publishers.

Brush, S. B., R. Kesseli, R. Ortega, P. Cisneros, K. S. Zimmerer, and C. Quiros. 1995. "Potato Diversity in the Andean Center of Crop Domestication." Conservation Biology 9: 1189-98.

Cleveland, D. A., and S. C. Murray. 1997. "The World's Crop Genetic Resources and the Rights of Indigenous Farmers." Current Anthropology 38: 477-515.

Coase, R. H. 1960. “The Problem of Social Cost.” Journal of Law and Economics 3: 1-44

—. 1974. "The Lighthouse in Economics." Journal of Law and Economics 17: 357-376. 
—. 1988. "Notes on the Problem of Social Cost." The Firm, The Market and the Law. Chicago: University of Chicago Press.

Cox, T. S. 1991. "The Contribution of Introduced Germplasm to the Development of U.S. Wheat Cultivars." In Use of Plant Introductions in Cultivar Development: Part 1, edited by H. L. Shands and L. E. Wiesner. Madison, WI: Crop Science Society of America, Inc.

Esquinas Alcazar, J. 1998. "Farmers' Rights." In Agricultural Values of Plant Genetic Resources, edited by R.E. Evenson, D. Gollin, and V. Santaniello. Wallingford, UK: CBI Publishing.

Evenson, R. E., D. Gollin, and V. Santaniello, eds. 1998. Agricultural Values of Plant Genetic Resources. Wallingford, UK: CBI Publishing.

FAO. 1996. Report on the State of the World's Plant Genetic Resources. Rome: Food and Agricultural Organization of the United Nations.

Fowler, Cary, and P.R. Mooney. 1990. Shattering: Food, Politics, and the Loss of Genetic Diversity. University of Arizona Press, Tuscon, AZ.

Genetic Resources Conservation Program, University of California, Division of Agriculture and Natural Resources. 2000. "McKnight Foundation-MILPA Project: McKnight Integrated Landrace Preservation Activity." Available at <http://www.grcp.ucdavis.edu/milpa/mil-main.htm>.

Gollin, M. A., and S. A. Laird. 1996. "Global Politics, Local Actions: The Role of National Legislation in Sustainable Biodiversity Prospecting." Boston University Journal of Science and Technology Law, available from Lexis: 2 B. U. J. Sci. and Tech. L. 16.

Harlan, J. R. 1975. “Our Vanishing Genetic Resources.” Science 188: 618-621.

King, S. R., T. J. Carlson and K. Moran. 1996. "Biological Diversity, Indigenous Knowledge, Drug Discovery, and Intellectual Property Rights." In Valuing Local Knowledge: Indigenous People and Intellectual Property Rights, edited by S. Brush and D. Stabinsky. Washington, DC: Island Press.

Lesser, W. 1998. Sustainable Use of Genetic Resources under the Convention on Biological Diversity: Exploring Access and Benefit Sharing Issues. Wallingford, UK: CAB International.

Louette, D., A. Charrier and J. Berthaud. 1997. "In Situ Conservation of Maize in Mexico, Genetic Diversity and Maize Seed Management in a Traditional Community." Economic Botany 51: 20-39.

Meng, E., J. E. Taylor, and S. B. Brush. 1998. "Implications for the Conservation of Wheat Landraces in Turkey from a Household Model of Varietal Choice." In Farmers, Gene Banks and Crop Breeding: Economic Analyses of Diversity in Wheat, Maize, and Rice, edited by M. Smale. Boston: Kluwer Academic Publishers.

Nabhan, G. P. 1985. "Native Crop Diversity in Aridoamerica: Conservation of Regional Gene Pools." Economic Botany 39: 387-99. 
National Research Council. 1993. Managing Global Genetic Resources: Agricultural Crop Issues and Policies. Washington, DC: National Academy Press.

Odek, James O. 1994. "Bio-Piracy: Creating Proprietary Rights in Plant Genetic Resources.” Journal of Intellectual Property Law 2: 141-181.

Perales, H., S. B. Brush, and C. O. Qualset. 1998. "Agronomic and Economic Competitiveness of Maize Landraces and In Situ Conservation in Mexico." In Farmers, Gene Banks and Crop Breeding: Economic Analyses of Diversity in Wheat, Maize, and Rice, edited by M. Smale. Boston: Kluwer Academic Publishers.

Posey, D. A., and G. Dutfield. 1996. Beyond Intellectual Property: Toward Traditional Resource Rights for Indigenous Peoples and Local Communities. Ottawa: International Development Research Centre.

Republic of the Philippines. 1997. Bicameral Conference Committee Report on Senate Bill 1728 and House Bill No. 9125. Congress of the Philippines. Tenth Congress, Third Regular Session.

Robinson, Nicholas A., ed. 1993. Agenda 21: Earth's Action Plan. New York: Oceana Publications, Inc.

Ronald, P. C. 1997. “Making Rice Disease Resistant.” Scientific American 227 (5): 68-73.

Sedjo, R. A. 1992. "Property Rights, Genetic Resources, and Biotechnological Change." Journal of Law and Economics 35: 199-213.

Shiva, V. 1997. Biopiracy: The Plunder of Nature and Knowledge. Boston: South End Press.

Sperling, L., and M. Loevinsohn, eds. 1997. Using Diversity: Enhancing and Maintaining Genetic Resources On-Farm. Ottawa and New Delhi: International Development Research Centre.

Soleri, D., and D. A. Cleveland. 1993. "Hopi Crop Diversity and Change." Journal of Ethnobiology 13: 203-31.

Tesemma, T., and E. Bechere. 1998. "Developing Elite Durum Wheat Landrace Selections (Composites) for Ethiopian Peasant Farm Use: Raising Productivity while Keeping Diversity Alive." Euphytica 102: 323-328.

van Zandt, D. E. 1993. "The Lessons of the Lighthouse: 'Government' or 'Private' Provision of Goods.” Journal of Legal Studies 22: 47-72.

Vogel, J. H. 1994. Genes for Sale: Privatization as a Conservation Policy. New York: Oxford University Press.

Wallace, H. A., and W. L. Brown. 1988. Corn and its Early Fathers. Ames, Iowa State University Press. 
Wasik, J. F. 1996. Green Marketing and Management: A Global Perspective. Cambridge, MA: Blackwell Business

Wellhausen, E. J., L.M. Roberts, and E. Hernandez X. 1952. Races of Maize in Mexico: Their Origin, Characteristics, and Distribution. Cambridge, MA: The Bussey Institution, Harvard University.

Witcombe, J. R., A. Johsi, K. D. Johsi, and B. R. Sthapit. 1996. "Farmer Participatory Crop Improvement. I: Varietal Selection and Breeding Methods and their Impact on Biodiversity." Experimental Agriculture 32: 445-460.

Wood, D., and J. M. Lenné. 1997. "The Conservation of Agrobiodiversity On-Farm: Questioning the Emerging Paradigm.” Biodiversity and Conservation 6: 109-129.

Zeven, A. C. 1999. "The Traditional Inexplicable Replacement of Seed and Seed Ware of Landraces and Cultivars; Review." Euphytica 110: 181-191. 


\section{The Author}

Stephen B. Brush is a professor of human and community development at the University of California, Davis. He has worked in the field of international agricultural development for 30 years, beginning with service as a Peace Corps Volunteer in Peru (1965-1967). An anthropologist by training, his research focuses on the cultural ecology and resources of traditional agricultural systems. He has conducted long-term research in Peru, Mexico and Turkey. He has studied the indigenous knowledge and maintenance of crop genetic diversity by potato farmers in the Andes of Peru, maize farmers in Mexico, and wheat farmers in Turkey. Brush was Program Director for Anthropology at the National Science Foundation and Senior Scientist at the International Plant Genetic Resources Institute, where he helped to develop a worldwide program for on-farm conservation of genetic resources.

\section{The Natural Assets Project}

The Natural Assets Project, based at the Political Economy Research Institute of the University of Massachusetts, Amherst, is a collaborative initiative launched with support from the Ford Foundation. The project aims to promote critical analysis and discussion of the potential for building natural assets individual and social wealth based on natural resources and ecosystem services - to advance the goals of poverty reduction, environmental protection, and environmental justice. 


\section{WORKING PAPERS}

\section{Program in Development, Peacebuilding, and the Environment}

\section{Political Economy Research Institute}

Anil Agarwal and Sunita Narain, Redressing Ecological Poverty Through Participatory Democracy: Case Studies From India. Working Paper No. DPE-00-01, December 2000.

K. A. Dixon, Reclaiming Brownfields: From Corporate Liability To Community Asset. Working Paper No. DPE-01-01, January 2001.

Manuel Pastor, Building Social Capital To Protect Natural Capital: The Quest for Environmental Justice. Working Paper No. DPE-01-02, January 2001.

Paul H. Templet, Defending the Public Domain: Pollution, Subsidies, and Poverty. Working Paper No. DPE-01-03, January 2001.

Gerald Friedman, The Sanctity of Property in American Economic History. Working Paper No. DPE-01-04, February 2001.

Peter Barnes and Marc Breslow, Pie in the Sky? The Battle for Atmospheric Scarcity Rent. Working Paper No. DPE-01-05, February 2001.

Nicolaas W. Bouwes, Steven M. Hassur and Marc D. Shapiro, Empowerment Through Risk-Related Information: EPA's Risk-Screening Environmental Indicators Project. Working Paper No. DPE01-06, February 2001.

Michael E. Conroy, Can Advocacy-Led Certification Systems Transform Global Corporate Practices? Evidence, and Some Theory. Working Paper No. DPE-01-07, September 2001.

Rao, J. Mohan, Globalization and the Fiscal Autonomy of the State. Working Paper No. 25, 2001.

D’Arista, Jane et al., Democratizing Global Economic Governance: A PERI Symposium. Working Paper No. 26 (DPE-01-08), December 2001.

Brush, Stephen B., The Lighthouse and the Potato: Internalizing the Value of Crop Genetic Diversity. Working Paper No. 37, March 2002. 